\title{
KARAKTERISTIK ARSITEKTUR DI KOTA LAMA KUDUS
}

\author{
Anisa ${ }^{1, *}$ \\ ${ }^{1}$ Program Studi Arsitektur Fakultas Teknik Universitas Muhammadiyah Jakarta \\ Cempakaputih Tengah 27 Jakarta Pusat 10510 \\ *anisa@ftumj.ac.id
}

\begin{abstract}
ABSTRAK. Kota Lama Kudus atau yang lebih sering disebut Kudus Kulon adalah sebuah kawasan bersejarah yang berada di Kabupaten Kudus, Propinsi Jawa Tengah. Kabupaten Kudus terbagi menjadi dua yaitu Kudus Kulon dan Kudus Wetan dengan sebuah sungai sebagai pemisah kedua area tersebut. Kudus Kulon atau Kota Lama Kudus merupakan cikal bakal kota Kudus dan sebuah tempat bersejarah dengan adanya makam Sunan Kudus dan Masjid Menara Kudus. Kudus yang kita kenal sekarang ini selain adanya Masjid Menara dan Makam Sunan Kudus, juga terkenal karena industri rokok. Dalam sejarah dikisahkan dahulu industri rokok berkembang mulai dari home industry di Kota Lama Kudus sekitar tahun 1900. Jauh sebelum industri rokok berkembang, sudah ada perdagangan yang memajukan daerah Kota Lama Kudus yaitu perdagangan palawija dan tembakau.
\end{abstract}

Penelitian ini merupakan penelitian deskriptif kualitatif yang mendeskripsikan serta menginterpretasikan karakteristik arsitektur Kota Lama Kudus. Deskripsi dan interpretasi ini penting dilakukan karena kondisi terkini Kota Lama Kudus sudah mengalami banyak perubahan. Data diambil melalui observasi lapangan tentang kondisi rumah, permukiman dan kawasan Kota Lama Kudus. Pada daerah sekitar Masjid dan Menara Kudus, permukiman didominasi oleh rumah-rumah Kilungan sehingga membentuk jalan-jalan berbentuk lorong seperti labirin. Semakin jauh dari Masjid dan Menara Kudus bentuk permukimannya berubah menjadi rumah-rumah terbuka tanpa dinding kilungan. Selain lingkungan permukimannya, arsitektur rumah di Kota Lama Kudus juga beragam. Ada rumah tradisional Kudus dengan bangunan sisir (tempat usaha), rumah tradisional Kudus tanpa bangunan sisir, rumah gedong (gaya eropa) dan rumah kilungan (rumah di dalam pagar tinggi). Tiga arsitektur rumah tersebut adalah asli sebagai karakteristik arsitektur Kota Lama Kudus. Faktor yang mempengaruhi karakteristik arsitektur di Kota lama Kudus adalah aktivitas yang di lakukan di kawasan tersebut

Kata Kunci: karakteristik, arsitektur, rumah, permukiman, Kota Lama Kudus

ABSTRACT. Kota Lama Kudus or more commonly called Kudus Kulon is a historic area located in Kudus District, Central Java Province. Kudus District is divided into two namely Kudus Kulon and Kudus wetan with a river as a separator of both areas. Kudus Kulon or Kota Lama Kudus is the forerunner of Kudus city and a historic place with the tomb of Sunan Kudus and Mosque of Menara Kudus. Kudus that we know today besides the existence of the Masjid Menara and the Tomb of Sunan Kudus, also famous for the cigarette industry. In the history of the first cigarette industry began to grow from the home industry in the Kudus Old City around the year 1900. Long before the cigarette industry develops, there is a trade that promotes the area of the Old Town Kudus palawija and tobacco trade.

This research is qualitative descriptive research that describes and interpret the architectural character of Kota Lama Kudus. These descriptions and interpretations are essential because the current condition of the Kudus Old City has undergone many changes. The data was taken through field observations on the condition of houses, settlements and the area of the Old City. In the area around the Mosque and the Menara, the settlements are dominated by Kilungan houses to form alleyshaped streets such as labyrinths. The farther away from the Mosque and the Menara form the settlements are transformed into open houses without the globe walls. In addition to its residential neighborhood, the architecture of the house in the Kudus Old City also varied. There is a traditional Kudus house with a sisir building (place of business), a traditional Kudus house without a sisir building, a gedong house (European style) and a kilungan house (house inside a high fence). The three architectural houses are genuine and are a character of the architecture of the Kudus Old City. Factors affecting the architectural characteristics of the old city of Kudus are the activities undertaken in the region

Keywords: characteristics, architecture, house, settlement, kudus Old City 


\section{PENDAHULUAN}

Kota Kudus adalah sebuah daerah setingkat Kabupaten yang termasuk dalam wilayah propinsi Jawa Tengah. Berjarak sekitar $51 \mathrm{~km}$ dari kota Semarang sebagai ibukota propinsi Jawa Tengah. Kudus mempunyai suatu daerah bersejarah yang sering disebut kota Lama Kudus atau sering disebut dengan Kudus Kulon. Daerah Kota Lama ini menjadi tujuan wisata peziarah dengan adanya Masjid AlAqso (Masjid Menara Kudus) dan makam Sunan Kudus sebagai salah seorang dari walisongo.

Selain adanya daerah Kota Lama Kudus, di Kota Kudus juga terkenal karena industry rokok. Awalnya, pusat dari home industry rokok tersebut ada di Kota Lama Kudus. Namun kemudian justru berkembang di belahan Kudus yang lain yaitu Kudus wetan. Pembagian Kudus menjadi Kudus Kulon dan wetan ini ditandai dengan sebuah sungai yang membentang utara-selatan bernama kaligelis.

Kota Lama Kudus, selain menjadi tujuan wisata religi juga mempunyai karakteristik yang istimewa yaitu adanya permukiman yang khas. Permukiman tersebut berisi rumahrumah dengan arsitektur yang mencirikan karakter khas masyarakatnya. Selain rumahrumah yang khas, permukimannya juga mempunyai ciri khusus yang berbeda dengan kota lama di tempat lain.

Ada beberapa penelitian yang sudah pernah dilakukan sebagai pendahuluan, antara lain penelitian tentang Studi Awal Pola Spasial Permukiman Di Kota Lama Kudus Studi Kasus : Desa Demangan, dan penelitian tentang Sistem Fisik Rumah Gedong sebagai Aplikasi Karakteristik Arsitektur Indis di Kota Lama Kudus.

Penelitian tentang studi awal pola spasial merupakan penelitian eksploratif yang menggali pola spasial permukiman yang ada di Desa Demangan sebagai salah satu desa di Kota Lama Kudus. [1]

Sistem Fisik rumah gedong sebagai aplikasi karakteristik arsitektur Indis di Kota Lama Kudus, mendeskripsikan rumah gedong dengan bantuan teori Sistem Fisik. Didapatkan bahwa bangunan indis di Indonesia digunakan untuk menyebut bangunan-bangunan yang bercorak eropa/barat. Bangunan dengan corak arsitektur indis banyak ditemukan di Kota Lama Kudus dengan nama rumah gedong. Temuan karakteristik dari sistem fisik rumah adalah sebagai berikut : bahan yang digunakan untuk penutup atap adalah genteng dengan bentuk atap limasan atau kampung yang dikombinasi dengan dinding gevel sebagai pemanis pada segitiga atap. Hal lain yang ditemukan ada/ah adanya peninggian lantai pada semua rumah. Peninggian lantai ini minimal 3 undak yaitu sekitar $60 \mathrm{~cm}$. [2]

Berdasarkan latar belakang tersebut maka dilakukan penelitian dengan rumusan masalah sebagai berikut :

1. Bagaimanakah karakteristik arsitektur Kota Lama Kudus?

2. Faktor apakah yang mempengaruhi karakteristik arsitektur tersebut?

\section{METODE PENELITIAN}

Penelitian tentang karakteristik arsitektur merupakan jenis penelitian deskriptif dengan data dan analisis kualitatif. Deskriptif kualitatif yang dimaksud adalah mengidentifikasi, mendeskripsikan serta menginterpretasikan karakteristik arsitektur Kota Lama Kudus. Pengumpulan data dilakukan melalui observasi lapangan tentang kondisi rumah, permukiman dan kawasan Kota Lama Kudus. Data observasi dilengkapi dengan data wawancara untuk mengungkap hal-hal yang sifatnya non fisik.

Pengumpulan data dengan observasi dan wawancara menggunakan kerangka teori tentang karakteristik arsitektur dari Habraken. Menurut Habraken (1978), untuk memahami karakteristik arsitektur dapat dilakukan dengan melihat obyek tersebut sebagai satu kesatuan yang terdiri dari spatial system, physical system dan stylistic system. spatial system (sistem spasial), berkaitan dengan organisasi ruang, mencakup hubungan ruang, hirarki ruang, orientasi, pola hubungan ruang dan lain sebagainya. physical system (sistem fisik), mencakup penggunaan material (bahan) dan konstruksinya. stylistic system (sistem bentuk), yaitu kesatuan komponen yang mewujudkan bentuk, meliputi bentuk bangunan dan elemen bangunan. [3]

Pada penelitian ini, spatial system, physical system dan stylistic system akan digunakan pada tahapan pengumpulan data dan analisis. Analisis dilakukan melalui tiga tahap. Tahap pertama adalah pemilahan data atau sering disebut reduksi data. Sesudah data direduksi, maka data diberikan kode untuk mempermudah proses analisis. Tahap kedua adalah tahap klasifikasi. Pada analisis pengklasifikasian data berdasar kategori yang 
ditemukan dari observasi dan wawancara dan disajikan dalam bentuk tabel. Tahapan ketiga adalah deskripsi dan interpretasi data sampai ditemukan tema-tema temuan. Tema-tema temuan yang berkaitan dengan karakteristik arsitektur kemudian didialogkan untuk mendapatkan kesimpulan akhir.

\section{HASIL DAN PEMBAHASAN}

\section{Karakteristik Arsitektur}

Dalam kamus besar Bahasa Indonesia, karakteristik berasal dari kata dasar karakter yang memiliki arti sifat-sifat kejiwaan, akhlak atau budi pekerti yang membedakan seseorang dengan yang lain; tabiat atau watak. Sedangkan karakteristik memiliki arti mempunyai sifat khas sesuai dengan perwatakan tertentu.

Pengertian karakter relatif berkaitan dengan alam sebagai pengaruh eksternal atau faktor lokal terhadap karakter atau karya arsitektur yang terdiri dari udara, iklim dan tanah. Adanya faktor eksternal terhadap karya arsitektur dapat mempengaruhi karakter dari peradaban atau seni suatu bangsa. [4]

Menurut Hastati ada dua hal yang dapat diperoleh melalui pendekatan karakteristik arsitektural ini yaitu karakter fisik yang terlihat dan karakter non fisik yaitu hal-hal yang tidak terlihat (hubungannya terhadap faktor-faktor lain seperti sosial, budaya, politik, iklim dan lain lain). Karakter fisik adalah hal-hal yang terlihat pada fisik sebuah bangunan meliputi keseluruhan aspek arsitektural yang terkait pada bangunan tersebut dan lingkungan yang melingkupinya. [4]

\section{Masjid, Menara dan Makam di Kawasan Kota Lama Kudus}

Karakteristik arsitektur di Kota Lama Kudus dipengaruhi oleh sebuah bangunan bersejarah yang ada di dalamnya. Bangunan bersejarah yang dimaksud adalah Masjid Menara Kudus yang didirikan oleh Sunan Kudus. Masjid ini dilengkapi dengan makam. Kompleks masjid dan makam ini menjadi salah satu tujuan wisata religi yaitu ziarah yang menjadi satu dengan ziarah walisongo.

Di dalam kawasan Menara Kudus terdapat beberapa aset budaya yang layak untuk dipertahankan antara lain masjid Al Aqsha, Menara Kudus, Klenteng, Rumah Tradisional Kudus, Masjid Bubar, Makam Sunan Kudus, dan masih banyak lagi asset budaya yang dimilikinya. Semua asset tersebut mengundang wisatawan baik yang bertujuan untuk ziarah ke makam sunan Kudus ataupun para peneliti yang tertarik dengan kawasan ini. [5]

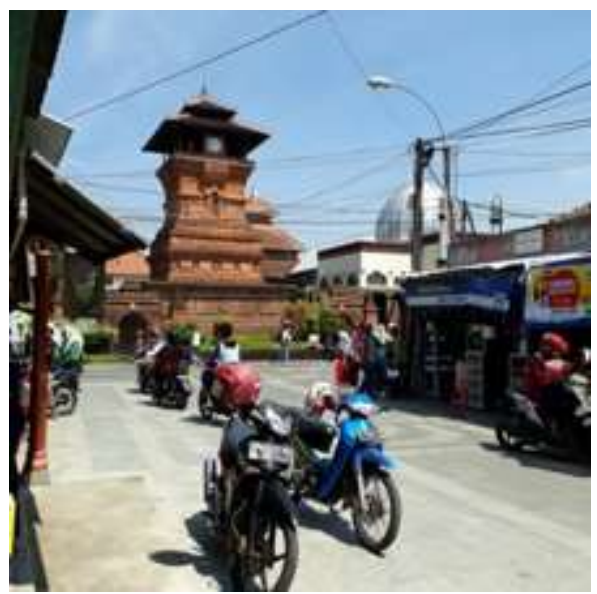

Gambar 1. Menara Kudus

(Sumber: Observasi Lapangan, 2018)

Banyaknya wisatawan yang mengunjungi Makam dan Masjid Menara Kudus menyebabkan terjadinya aktivitas ekonomi di sekitarnya. Aktivitas ekonomi yang timbul beragam bentuknya, antara lain berjualan di dekat Menara, menyewakan tempat parkir, Kamar mandi, dan juga persewaan tempat peristirahatan.

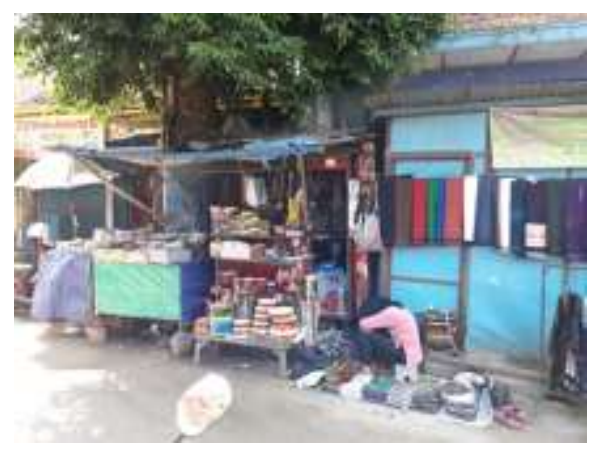

Gambar 2. Aktivitas Ekonomi

(Sumber: Observasi Lapangan, 2018)

\section{Lingkungan di Kawasan Kota Lama Kudus}

Rumah-rumah yang ada di sekitar menara Kudus kebanyakan adalah Rumah Kilungan. Tembok kilungan itulah yang kemudian membentuk jalan yang berliku dan sempit. Perkecualian pada rumah-rumah yang ada di sekitar pawestren, rumah berbentuk deret dan terbuka.

Bisa dilihat bahwa di sekitar Menara Kudus, tidak terdapat ruang terbuka untuk umum. Ruang terbuka yang ada hanyalah ruang terbuka milik pribadi dan ruang terbuka di masjid dan makam. 


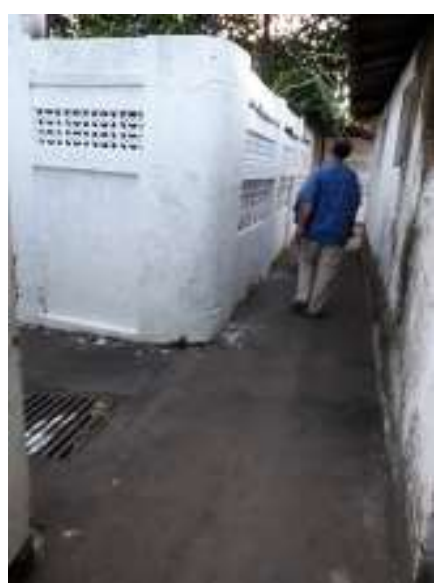

Gambar 3. Jalan lingkungan

(Sumber: Observasi Lapangan, 2018)

Sedangkan lingkungan di sekitar Menara Kudus didominasi dengan pemanfaatan kegiatan ekonomi pada rumah-rumah yang ada. Bisa dilihat bahwa rumah-rumah yang ada di tepi jalan terutama yang berdekatan dengan Menara Kudus, membuka rumahnya untuk kegiatan ekonomi.

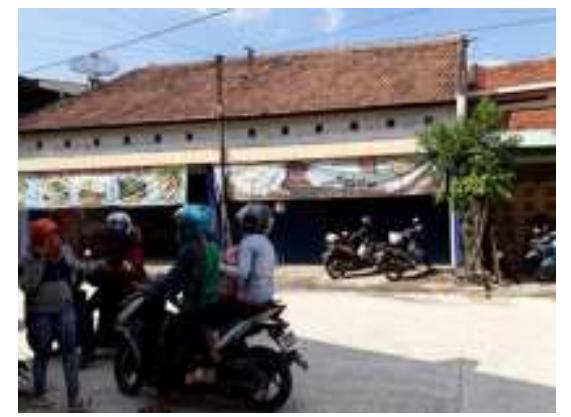

Gambar 4. Membuka usaha di dalam rumah (Sumber: Observasi Lapangan, 2018)

Selain membuka bagian rumahnya untuk usaha atau menyewakan tempat, ada juga yang berjualan di tepi jalan. Para penjual yang berjualan di tepi jalan ada yang menggunakan bahu jalan namun ada juga yang menggunakan halaman rumah.

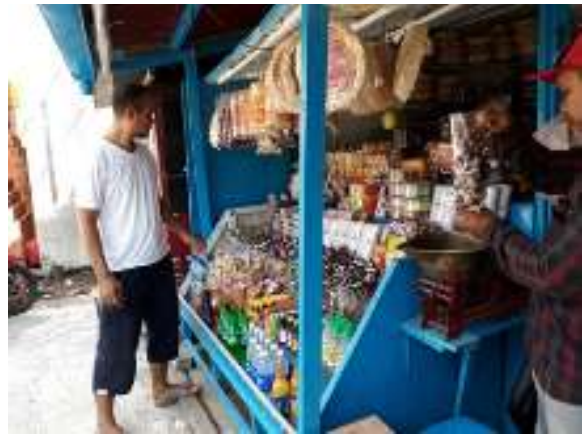

Gambar 5. Berjualan di Tepi jalan (Sumber: Observasi Lapangan, 2018)

\section{Sistem Spasial}

Permukiman asli masyarakat Kota Lama Kudus berupa permukiman deret yang terdiri dari beberapa rumah dan bangunan penunjang yang ada di depannya. Beberapa rumah tersebut disatukan dan berpusat pada latar (halaman) serta diiberi pembatas pagar tanaman. Seiring dengan perkembangan perekonomian, mulai dibangunlah rumahrumah yang dikelilingi tembok masif yang tinggi. Tembok masif ini bisa merupakan pagar atau bagian dari bangunan dan di sebut dengan kilungan. [6]

Spatial system (sistem spasial), berkaitan dengan organisasi ruang, mencakup hubungan ruang, hirarki ruang, orientasi, pola hubungan ruang dan lain sebagainya. Dalam konteks kawasan, sistem spasial dapat dianalisis melalui pola ruang, orientasi/arah hadap rumah, hirarki bangunan.

Arah hadap rumah-rumah yang ada di Kota Lama Kudus beragam. Namun secara umum dapat dikelompokkan menjadi dua yaitu berdasarkan arah mata angin (utara-selatanbarat-timur) dan berdasarkan pada obyek tertentu yang menjadi pusat orientasi.

\section{Arah hadap dan orientasi Bangunan Utama}

Ada tiga arah mata angin yang digunakan sebagai arah hadap atau orientasi bangunan yaitu selatan, timur, dan barat. Arah hadap bangunan utama sangat tergantung dari bentuk bangunan tersebut dan letaknya dalam permukiman.

Bangunan utama menghadap selatan. Bangunan utama yang menghadap ke selatan biasanya mempunyai bentuk asli rumah tradisional Kudus. Alasan dibuat rumah ke arah selatan ada hubungannya dengan matahari dan perletakan kamar dalam rumah. Dahulu di Kudus kebanyakan rumah adalah 
berbentuk tradisional Kudus dengan kamar (sentong) berada di bagian belakang.

Pada saat musim penghujan, matahari bersinar lebih lama di sebelah utara sehingga kamar diletakkan di sebelah utara dan bangunan dihadapkan ke arah selatan. karena kamar tidur merupakan daerah yang sifatnya pribadi maka diletakkan paling jauh dari daerah yang dapat dijangkau orang banyak. Adanya kamar tidur yang diletakkan pada sebelah utara maka ketika musim hujan akan mendapat sinar matahari yang lebih banyak dan kamar menjadi hangat. Kemudian saat musim panas, matahari akan bersinar lama diselatan dan sinar matahari yang masuk ke kamar tidak terlalu panas karena kamar terletak di utara. Pada intinya mereka berusaha tetap memasukkan sinar matahari tetapi disesuaikan dengan kebutuhan dan menghindari sengatan panas yang menyilaukan.

Penelitian ini mengambil 14 kasus. Dari 14 kasus yang diteliti ada 12 kasus yang mempunyai arah hadap bangunan utama ke selatan. Dari 12 kasus tersebut semua mempunyai bentuk asli rumah tradisional Kudus dan ada 3 kasus yang sekarang ini sudah berubah fasadnya tetapi arah hadap masih dipertahankan.

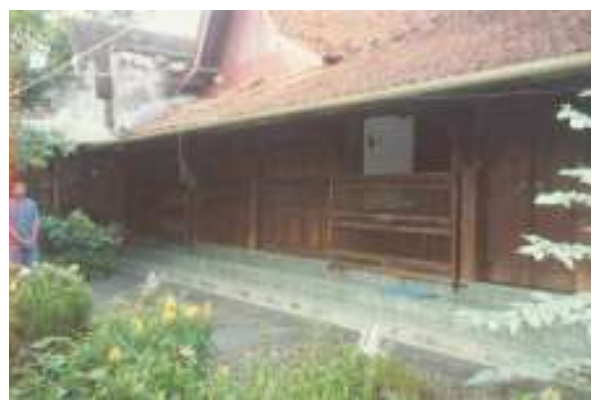

Gambar 6. Rumah Tradisional Kudus (Sumber: Observasi Lapangan, 2003)

Kasus satu yang arah hadap bangunan utama menghadap ke selatan, mempunyai lahan memanjang utara-selatan dan mempunyai letak rumah tinggalnya ada di ujung/pojok utara. Bangunan utama berada paling ujung utara dan menghadap ke selatan yaitu pada halaman yang ada didepannya. Pada sisi sebelah barat terdapat bangunan untuk kamar mandi, sumur dan gotakan (pawon masak). Sedangkan pada bagian sebelah timur terdapat bangunan yang dahulu sempat digunakan untuk pabrik rokok Mustikaning Rokok. Pada bagian ujung selatan terdapat bangunan memanjang yaitu kamar mandi dan sumur yang berjumlah 6 buah dan satu kandang ayam. Berdekatan dengan gotakan ada sedikit lahan yang digunakan untuk kebonan. Pada beberapa kasus yang diteliti selalu menyediakan sebagian tanahnya untuk menanam pepohonan.

Kasus yang lain, lahan memanjang utaraselatan. Pada bagian rumah tinggal terletak di ujung utara lahan dan menghadap ke selatan. Aslinya dahulu ini adalah rumah Kudus dengan gebyok kayu tetapi tidak memiliki lantai gladagan. Pada ujung selatan kilungan terdapat bangunan yang dahulu digunakan sebagai tempat usaha yaitu bangunan untuk penyimpanan barang dagangan. Sebenarnya dalam satu kilungan ini ada 3 bangunan yang digunakan untuk usaha yaitu pada ujung barat, ujung selatan dan ujung timur. Aslinya ketiga bangunan tersebut adalah gudang palawija dan tembakau. Walaupun dalam rumah ini terdapat juga usaha pabrik Rokok Kumoro, namun pelaksanaan pembuatan rokok itu sendiri dilakukan pada bangunan yang dikhususkan untuk pabrik.

Pada tahun 1975 bangunan yang ada di ujung selatan difungsikan sebagai rumah tinggal setelah didahului dengan pelebaran gudang belakang (sebelah barat). Kemudian pada tahun 1996 karena adanya pelebaran jalan, maka satu ruangan yang ada pada bagian paling timur terpotong untuk pelebaran jalan sehingga hilanglah satu ruang memanjang tersebut. Pada bagian tengah lahan yang memanjang utara-selatan tersebut (K1 dan K2) ada halaman yang sampai sekarang masih dipertahankan.

Pada 12 kasus rumah yang berbentuk asli tradisional Kudus dan menghadap ke selatan/kidul, ada dua macam perletakan bangunan utama dalam kilungan. Perletakan bangunan utama ada yang pada ujung utara/lor dan ada yang berada di tengah antara 2 halaman. Setiap rumah yang menghadap ke selatan pasti di depannya terdapat halaman/latar.

Bangunan utama menghadap timur. Rumah di dalam kilungan yang mempunyai bangunan utama tidak menghadap ke selatan ada satu kasus dari 14 kasus yang diteliti.

Bangunan yang ada pada bagian paling timur atau yang paling berdekatan dengan jalan adalah bangunan gudang dan pabrik rokok. Antara rumah tinggal yang menghadap timur dan jalan ada halaman/latar ngarep yang memungkinkan rumah dapat dilihat secara 
utuh dari arah pintu. Rumah ini mempunyai bangunan utama berbentuk gedong/eropa yang dibangun pada awal tahun 1900-an. Dari awal rumah ini berdiri bentuknya gedong dan dipagari kilungan pada 3 sisinya.

Bangunan utama menghadap barat/kulon. Ada satu rumah dari 14 rumah yang menjadi kasus penelitian mempunyai bangunan utama menghadap kulon. Rumah ini menghadap ke barat yaitu arah jalan besar yang ada di depannya. Rumah ini mempunyai bangunan utama berbentuk rumah gedong/eropa. Karena rumahnya menghadap ke jalan yaitu arah barat maka secara otomatis ruang yang berada di bagian depan/barat adalah ruang tamu. Ruang yang digunakan untuk berkumpul bersama keluarga berada di antara ruang tamu dan kamar. Susunan ruang di dalam rumah pada rumah gedong/eropa berbeda dengan rumah Kudus. Pada rumah gedong/eropa susunan ruang mirip dengan rumah-rumah yang ada sekarang ini.

Tabel 1. Arah hadap dan Orientasi Bangunan Utama

\begin{tabular}{|c|c|l|l|}
\hline \multirow{2}{*}{ Kasus } & \multicolumn{3}{|c|}{ Arah hadap/orientasi bangunan } \\
\hline & selatan & timur & barat \\
\hline K 1 & $\bullet$ & & \\
\hline K 2 & $\bullet$ & & \\
\hline K 3 & $\bullet$ & & \\
\hline K 4 & $\bullet$ & & \\
\hline K 5 & & $\bullet$ & \\
\hline K 6 & & & $\bullet$ \\
\hline K 7 & $\bullet$ & & \\
\hline K 8 & $\bullet$ & & \\
\hline K 9 & $\bullet$ & & \\
\hline K 10 & $\bullet$ & & \\
\hline K 11 & $\bullet$ & & \\
\hline K 12 & $\bullet$ & & \\
\hline K 13 & $\bullet$ & & \\
\hline K 14 14 & $\bullet$ & & \\
\hline \multicolumn{4}{|c|}{ (Sumber : analisis, 2018) } \\
\hline
\end{tabular}

\section{Pola Ruang pada Bangunan Utama}

Bangunan utama dari 14 kasus yang di teliti, sebagian besar (12 kasus) berbentuk rumah tradisional Kudus. Sedangkan 2 kasus yang lain adalah rumah gedong (eropa).

Rumah tradisional Kudus tipe lengkap terdiri dari 3 ruang inti yaitu jogosatru, gedongan, dan pawon. Jogosatru adalah ruang yang berhubungan langsung dengan pintu masuk ke dalam rumah. Dapat dikatakan bahwa jogosatru ini adalah ruang yang sifatnya publik. Jogosatru ini digunakan untuk menerima tamu.
Gedongan adalah ruang privat di dalam rumah. Gedongan yang asli berlantai lebih tinggi daripada jogosatru dan pawon sehingga terdapat bancik untuk naik dari jogosatru ke gedongan. Gedongan ini bermacam-macam fungsinya. Antara lain untuk menyimpan barang berharga dan untuk kamar. Di gedongan ini ada ruang utama yang dihiasi dengan gebyok khusus pada bagian pintu masuknya yaitu kamar yang terletak di tengah.

Sedangkan pawon adalah ruangan yang sifatnya semi publik. Pawon bisa digunakan untuk tempat berkumpul keluarga, untuk makan, dan juga sebagian digunakan sebagai dapur. Selain bangunan utama tersebut, pada rumah tradisional Kudus juga terdapat bangunan penunjang yang sering disebut dengan bangunan sisir. Bangunan sisir tersebut berada di depan bangunan utama, berhadapan dan dipisahkan dengan halaman. Terletak sejajar dengan bangunan sisir adalah sumur dan kamar mandi.

Sedangkan pola ruang pada rumah gedong adalah seperti rumah modern. Begitu juga penyebutannya, mulai dari ruang tamu, kamar tidur, ruang keluarga, dapur, kamar mandi, dll. Hanya bedanya pada tampilan luar bangunannya.

Penataan ruang pada rumah tradisional Kudus merespon aktivitas ekonomi tersebut dengan penyediaan ruang dan penataan hirarki ruang. Penyediaan ruang yang dimaksud adalah adanya sebuah bangunan yang terletak berhadapan dengan rumah tradisional Kudus bernama bangunan sisir. Bangunan sisir inilah yang merupakan perwujudan dari ruang yang dikhususkan untuk kegiatan ekonomi. Sedangkan untuk rumah yang tidak mempunyai bangunan sisir maka aktivitas ekonomi akan dilakukan di jogosatru sebagai ruang yang secara hirarkis merupakan ruang yang paling umum dan boleh dimasuki oleh semua orang (ruang publik). [7]

\section{Hirarki ruang, bangunan dan kawasan}

Hirarki ruang dalam rumah bisa dikelompokkan menjadi publik, semi publik, privat. Pada rumah tradisional Kudus, hirarki ruang tertinggi adalah pada gedongan. Gedongan secara fisik arsitektural ditandai dengan lantai yang lebih tinggi, pelingkunp ruangnya rapat, dan terdapat hiasan yang lebih kualitasnya daripada bagian lain. Pada rumah gedong, hirarki ruang tertinggi ada pada kamar tidur, yang ditandai dengan letak ruang 
tidur yang tidak terlihat dari ruang tamu dan untuk mengaksesnya harus melewati ruang semi publik yaitu ruang keluarga.

Hirarki bangunan yang di maksud adalah pada rumah-rumah yang ada di Kota Lama Kudus, kebanyakan ada bangunan inti dan bangunan penunjang yang terpisah. Hal ini sengaja dipisahkan secara fisik untuk memperlihatkan bahwa 2 bangunan ini terpisah secara hirarki walaupun secara penyebutan masih disebut satu rumah.

Hirarki dalam kawasan, berkaitan dengan letak rumah-rumah tersebut terhadap pusat Kota Lama yaitu Menara dan Makam Sunan Kudus. Semakin dekat rumah ke Menara Kudus maka hirarkinya lebih tinggi. Rumah-rumah yang dekat dengan Menara dan Makam Sunan Kudus didominasi dengan rumah berlahan luas dan berdinding pembatas (kilungan). Sehingga dari pagar-pagar kilungan tersebut terbentuk jalan-jalan berliku seperti lorong. Semakin menjauh dari Masjid dan Makam, maka bentuk rumah lebih terbuka, berderet tanpa pagar.

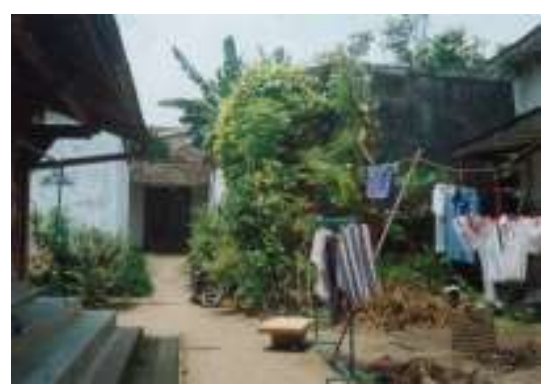

Gambar 7. Rumah Kilungan di dekat Menara (Sumber: Observasi Lapangan, 2003)

\section{Sistem Fisik}

physical system (sistem fisik), mencakup penggunaan material (bahan) dan konstruksinya. Dalam konteks kawasan sistem fisik dapat dianalisis melalui wujud fisik bangunan, material dan pembatas ruang.

Bahan bangunan yang digunakan dalam rumah-rumah yang diteliti mayoritas adalah kayu. Bahan bangunan yang digunakan terkait dengan bentuk bangunan utama. Apabila bangunan utama berbentuk rumah tradisional Kudus maka bahan bangunan yang digunakan adalah kayu. Karena rumah tradisional Kudus dibangun dari kayu yang bisa dirakit-lepas bagian per bagiannya. Kayu digunakan pada semua bagian rumah kecuali lantai. Dinding, atap, pembatas antar ruang semua menggunakan bahan kayu.
Tabel 2. Material pembentuk Rumah

\begin{tabular}{|c|c|c|c|}
\hline \multirow{2}{*}{ Kasus } & Material pembentuk rumah \\
\cline { 2 - 4 } & kayu & $\begin{array}{c}\text { Kayu dan } \\
\text { tembok }\end{array}$ & $\begin{array}{c}\text { Tembok } \\
\text { bata }\end{array}$ \\
\hline K 1 & $\bullet$ & $\bullet$ & \\
\hline K 2 & & $\bullet$ & \\
\hline K 3 & & & $\bullet$ \\
\hline K 4 & $\bullet$ & & $\bullet$ \\
\hline K 5 & & & \\
\hline K 6 & & & \\
\hline K 7 & $\bullet$ & & \\
\hline K 8 & $\bullet$ & & \\
\hline K 9 & $\bullet$ & & \\
\hline K 10 & $\bullet$ & & \\
\hline K 11 & $\bullet$ & & \\
\hline K 12 & & & $\bullet$ \\
\hline K 13 & $\bullet$ & & \\
\hline K 14 & $\bullet$ & & \\
\hline
\end{tabular}

(Sumber : analisis, 2018)

Pada rumah tradisional Kudus yang sudah direnovasi, biasanya ada penambahan bahan bangunan lain, yaitu tembok/dinding bata. Bagian bangunan yang berubah materialnya adalah pawon, yang merupakan ruang semi publik di dalam rumah.

Sedangkan rumah di kawasan Kota Lama yang menggunakan bahan bangunan tembok bata adalah rumah gedong atau rumah bergaya eropa.
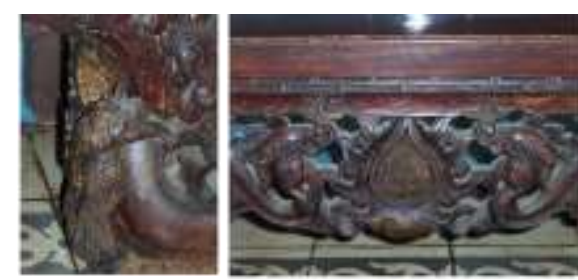

Gambar 8. Ornamen pada Bancik yang memisahkan jogosatru dengan gedongan (Sumber: Observasi Lapangan, 2005)

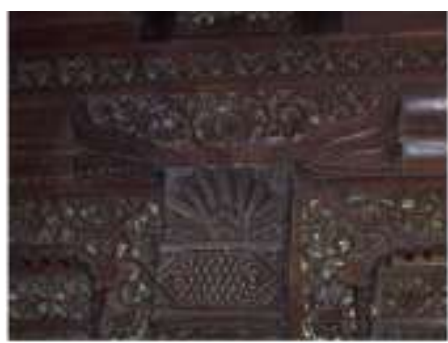

Gambar 9. Material kayu pada bagian Dinding (Sumber: Observasi Lapangan, 2005) 


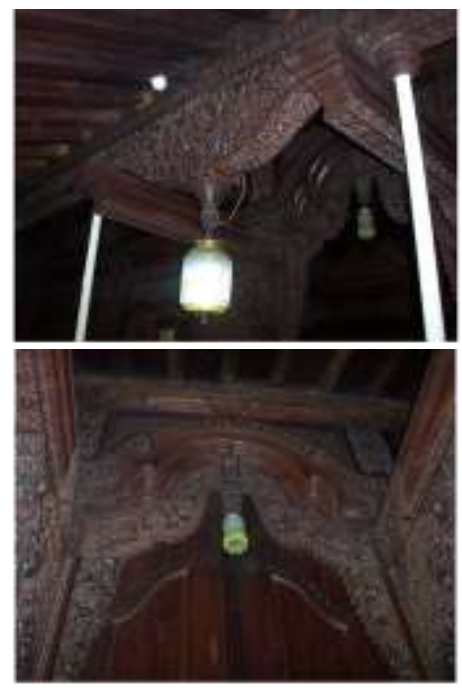

Gambar 10. Material kayu pada bagian Atas pintu dan atap

(Sumber: Observasi Lapangan, 2005)

\section{Sistem Stitistik/ bentuk}

stylistic system (sistem bentuk), yaitu kesatuan komponen yang mewujudkan bentuk, meliputi bentuk bangunan dan elemen bangunan. Dalam konteks kawasan, sistem bentuk dapat dianalisis melalui komponen pembentuk seperti atap, kolom, bukaan, ornament, dll.

Berdasarkan observasi didapatkan bahwa dari 14 rumah yang diteliti, ada 9 rumah dalam kondisi asli rumah tradisional Kudus, 3 rumah masih mempunyai pola rumah tradisional kudus namun fasadnya diubah, dan 2 rumah berbentuk eropa.

Tabel 3. Bentuk Rumah

\begin{tabular}{|c|c|c|c|}
\hline \multirow{2}{*}{ Kasus } & \multicolumn{3}{|c|}{ Bentuk bangunan utama } \\
\hline & $\begin{array}{c}\text { Rmh } \\
\text { kudus }\end{array}$ & $\begin{array}{c}\text { Fasad } \\
\text { diubah }\end{array}$ & $\begin{array}{c}\text { Rmh } \\
\text { eropa }\end{array}$ \\
\hline K 1 & $\bullet$ & & \\
\hline K 2 & & $\bullet$ & \\
\hline K 3 & & $\bullet$ & \\
\hline K 4 & $\bullet$ & & \\
\hline K 5 & & & $\bullet$ \\
\hline K 6 & & & $\bullet$ \\
\hline K 7 & $\bullet$ & & \\
\hline K 8 & $\bullet$ & & \\
\hline K 9 & $\bullet$ & & \\
\hline K 10 & $\bullet$ & & \\
\hline K 11 & $\bullet$ & & \\
\hline K 12 & \multicolumn{3}{|c|}{ (Sumber : analisis, 2018) } \\
\hline K 13 & $\bullet$ & $\bullet$ & \\
\hline K 14 & $\bullet$ & & \\
\hline \multicolumn{4}{|c|}{}
\end{tabular}

Komponen pembentuk ruang berupa elemen atap, kolom, bukaan, ornamen dan lainnya tergantung pada bentuk rumahnya. Pada rumah tradisional Kudus, bentuknya adalah bentuk asli. Dengan atap joglo dan pelana pada bagian pawon. Ornamennya adalah ukiran pada bagian-bagian tertentu pada rumah. Ukiran bisa berupa 2 dimensi dan 3 dimensi.

Pada rumah tradisional Kudus yang sudah berubah fasadnya, maka fasad baru menyesuaikan dengan bentuk modern. Namun pola ruang tidak dirubah. Pada rumah gedong, ornamen, pintu, jendela semua bercorak eropa. Atap berbentuk perisai dengan kemiringan 40-45 derajat.

Tabel 4. Ornamen pada Rumah

\begin{tabular}{|c|c|c|c|}
\hline \multirow[b]{2}{*}{ Kasus } & \multicolumn{3}{|c|}{ Ornamen } \\
\hline & $\begin{array}{c}\text { Tradisiona } \\
\text { I Kudus }\end{array}$ & $\begin{array}{c}\text { Tradisional } \\
\text { kudus dan } \\
\text { modern }\end{array}$ & $\begin{array}{c}\text { Eropa/ind } \\
\text { is/gedon } \\
\mathrm{g}\end{array}$ \\
\hline K 1 & - & & \\
\hline K 2 & & - & \\
\hline K 3 & & $\bullet$ & \\
\hline K 4 & - & & \\
\hline K 5 & & & $\bullet$ \\
\hline K 6 & & & - \\
\hline K 7 & - & & \\
\hline K 8 & - & & \\
\hline K 9 & - & & \\
\hline K 10 & $\bullet$ & & \\
\hline K 11 & - & & \\
\hline K 12 & & - & \\
\hline K 13 & - & & \\
\hline K 14 & - & & \\
\hline
\end{tabular}

(Sumber : analisis, 2018)

\section{KESIMPULAN}

Hasil yang didapatkan dari penelitian ini adalah lingkungan permukiman dan rumahrumah di Kota Lama Kudus mempunyai arsitektur yang unik dan beragam. Pada daerah sekitar Masjid dan Menara Kudus, permukiman di dominasi oleh rumah-rumah Kilungan sehingga membentuk jalan-jalan berbentuk lorong seperti labirin.

Semakin jauh dari Masjid dan Menara Kudus bentuk permukimannya berubah menjadi rumah-rumah terbuka tanpa dinding kilungan. Tetapi bentuknya masih rumah tradisiomal Kudus, hanya bentuknya berderet dan terbuka tanpa kilungan.

Selain lingkungan permukimannya, arsitektur rumah di Kota Lama Kudus juga beragam. Ada rumah tradisional Kudus dengan bangunan sisir (tempat usaha), rumah tradisional Kudus tanpa bangunan sisir, rumah gedong (gaya eropa) dan rumah kilungan (rumah di dalam pagar tinggi). Tiga arsitektur rumah tersebut 
adalah asli dan merupakan karakteristik arsitektur Kota Lama Kudus.

Apabila ditinjau dari teori Habraken, maka dapat disimpulkan karakteristik arsitektur berdasarkan 3 sistem yaitu sistem spasial, sistem fisik dan sistem bentuk. Berdasarkan sistem spasial di dapatkan bahwa rumahrumah di Kota Lama Kudus lebih banyak yang mengikuti arah hadap ke selatan. Bangunan rumah biasanya terdiri dari beberapa elemen bangunan yaitu bangunan utama dan bangunan penunjang (biasanya digunakan untuk usaha). Bangunan utama yang berbentuk rumah tradisional Kudus mempunyai pola rumah inti yang terdiri dari 3 ruang yaitu jogosatru, gedongan dan pawon. Hirarki ruang yang paling tinggi adalah ruang gedongan yang biasanya sekarang ini berupa kamar.

Kesimpulan dari sistem fisik adalah material yang digunakan untuk membentuk rumah tergantung dari bentuk rumahnya. Jika rumahnya berbentuk rumah tradisional Kudus maka material pembentuknya adalah kayu pada bagian samping dan atas rumah. Sedangkan pada bagian bawah berupa ubin dan plesteran/tanah.

Sistem bentuk mendapatkan kesimpulan bahwa rumah-rumah asli yang ada di Kota Lama Kudus adalah rumah tradisional Kudus. Saat ini ada yang masih asli bentuknya namun ada yang sudah berubah. Selain rumah tradisional Kudus, ada juga rumah yang disebut sebagai rumah gedong yaitu rumah bergaya arsitektur indis/eropa.

Faktor yang mempengaruhi karakteristik arsitektur di Kota lama Kudus adalah aktivitas yang di lakukan di kawasan tersebut. Kawasan Kota Lama Kudus dengan pusat Menara dan Makam Sunan Kudus identik dengan kawasan religius dimana masyarakatnya mempunyai dua aktivitas utama yaitu mengaji dan berdagang. Sehingga dua aktivitas itulah yang banyak mempengaruhi karakteristik arsitektur rumah-rumah di Kota Lama Kudus.

\section{DAFTAR PUSTAKA}

[1] Anisa. Studi Awal Pola Spasial di Kota Lama Kudus. Studi Kasus: Desa Demangan.

http://ejournal.gunadarma.ac.id/index.php /dekons/article/view/473

[2] Anisa, (2012). Sistem Fisik Rumah Gedong sebagai Aplikasi Karakteristik
Arsitektur Indis di Kota Lama Kudus. Jurnal Teknologi Vol 4 No 1 Januari 2012.

http://library.gunadarma.ac.id/journal/vie w/8110/sistem-fisik-rumahgedongsebagai-aplikasi-karakteristikarsitekturindis-di-kota-lama-kudus.html/

[3] Habraken. (1978). General Principles of about the Way Environment Exist. Department of Architecture MIT Massachusetts

[4] Hastati, F. (2003). Karakteristik Arsitektural Bangunan Indis pada Perumahan Pegawai Perusahaan Jawatan Kereta Api Pengok Blok A dan Blok B di Yogyakarta. Tesis S2 Arsitektur Fakultas Teknik Universitas Gadjah Mada.

[5] Anisa (2008). Studi Awal Pola Ruang Kawasan Menara Kudus. Jurnal Arsitektur NALARs Vol 7 No 1 Januari $\underline{2008}$

[6] Anisa. ( 2004). Rumah di dalam Kilungan di Kota Lama Kudus. Jurnal Arsitektur NALARs Vol 3 No 1 Januari 2004

[7] Anisa, (2017). Keterkaitan aktivitas Ekonomi dengan Tata Ruang Rumah tradisional Kudus di Kota Lama Kudus. Prosiding SEMNASTEK 2017. 
